148 VARIA

\title{
Modernizm a film autorski lat sześćdziesiątych $w$ Chorwacji
}

\author{
NIKICA GILIĆ \\ Faculty of Humanities and Social Sciences \\ University of Zagreb
}

\begin{abstract}
Gilić Nikica, Modernizm a film autorski lat sześćdziesiątych w Chorwacji [Modernism and auteurial Cinema in Croatia in the 1960s]. "Images" vol. XXV, no. 34. Poznań 2019. Adam Mickiewicz University Press. Pp. 148-154. ISSN 1731-450X. DOI 10.14746/i.2019.34.09.

Croatian film of the 1960s is colored by the poetics of auteurial cinema which was already emerging in the previous decade, but dominated in the 1960s, both in the production of cinema (both fiction films and animation), but also in the reception of these films with independent and ambitious critics. The text discusses the production modes of the era in Croatia and Yugoslavia, as well as several aspects of the poetics of cinematic modernism (its history and the importance of innovation), with Branko Ivanda's feature debut Gravity (Gravitacija), in which all sorts of stylistic experiments blend well with traditional motifs and cinematic procedures, anticipating Ivanda's auteuristic oevure.
\end{abstract}

KEYWORDS: modernism, auteurial cinema, croatian cinema, 1960s, Branko Ivanda, Gravity

\section{Wprowadzenie}

W dyskursie o chorwackim filmie lat sześćdziesiątych XX wieku często można spotkać pojęcie „film autorski”. To bowiem we wspomnianym okresie (nie tylko w Chorwacji) ugruntowała się tak zwana poetyka autorska, jak również specyficzny „autorski” model produkcji filmowej. Biorąc pod uwagę fakt, że zdecydowanie największym zainteresowaniem szerokiej publiczności cieszy się pełnometrażowy film fabularny, polityka kulturalna w dziedzinie kinematografii prowadzona jest zgodnie z jego

[1] Więcej o klasyfikacji genologicznej w: N. Gilić, Filmske vrsti i rodovi, Zagreb 2007.

[2] Mechanizmy produkcji tego okresu interpretowane są zgodnie z ustaleniami Iva Škrabala. Por. I. Škrabalo, 101 godina filma u Hrvatskoj 1896-1997. Pregled povijesti hrvatske kinematografije, Zagreb 1998. Publikacja ta stanowi również źródło większości informacji filmograficznych, które przywoływane są w tekście. Nowe, skrócone i zmienione, wydanie historiograficznych badań Škrabala może stanowić cenne źródło informacji, szczególnie dla osób, które po raz pierwszy stykają się z chorwacką kinematografią. Por. I. Škrabalo, Hrvatska filmska povijest ukratko (1896-2006), Zagreb 2008. specyfiką i potrzebami. Pojęcie „film autorski” najczęściej odnosi się właśnie do tego rodzaju filmu[1], dlatego poświęcę mu najwięcej uwagi, jak również powiążę ze zjawiskiem modernizmu, które w kulturze chorwackiej było obecne znacznie wcześniej niż zorganizowana kinematografia (po pierwszych poważniejszych próbach organizacji pod kolaboracyjną władzą ustaszowską, dopiero w totalitarnej socjalistycznej Jugosławii zaczęto budować system instytucji kinematograficznych).

\section{Ramy produkcji}

Pisząc o chorwackiej produkcji filmowej lat sześćdziesiątych XX wieku, należy być świadomym, że na obszarze całej SFRJ [Socjalistyczna Federacyjna Republika Jugosławii] postępował wówczas proces decentralizacji kinematografii oraz względnej liberalizacji politycznego i instytucjonalnego reżimu[2]. Zasady prawne regulujące kwestie związane $\mathrm{z}$ kinematografią podlegały stopniowym przemianom, w myśl których coraz częściej o produkcji filmów decydowano $\mathrm{w}$ poszczególnych socjalistycznych republikach ówczesnej federacji, rzadziej zaś w Belgradzie - stolicy federacyjnego państwa. 
Również znaczna część produkcji przeniosła się z dużych wytwórni filmowych do nowych (często zakładanych ad hoc) organizacji zrzeszających filmowców: mimo że w oficjalną komunistyczną politykę kulturową była wpisana idea wartości artystycznej, produkty państwowych wytwórni potrafiły być nachalnie populistyczne (np. Šeki snima, pazi se [Uważaj, Šeki nagrywa] Marijana Vajdy z 1962 roku)[3] - jakby zostały zrealizowane przez przedsiębiorstwa nastawione na wolny rynek zachodniego kapitalizmu. Duże wytwórnie filmowe mają bowiem swoją instytucjonalną logikę: $\mathrm{w}$ kapitalizmie celem jest wysoka sprzedaż biletów i zysk, w socjalizmie zaś rozszerzenie wpływu filmu (tym samym państwowej ideologii) na jak największą liczbę widzów. W obu przypadkach twórczy koncept artystyczny musi przebyć $\mathrm{w}$ produkcyjnym labiryncie długą drogę do filmowej realizacji (w socjalizmie mierząc się również z gremiami politycznych decydentów), co na ogół nie przynosi nadzwyczajnych efektów artystycznych.

Wspomniane nowe organizacje zrzeszające filmowców (tzw. Filmska radna zajednica [FRZ]), nierzadko powstawały dla realizacji jednego filmu fabularnego. Szczególnie interesujący i znamienny jest przypadek niezależnej wytwórni Filmski autorski studio (FAS) [4], która - działając na uboczu - zdołała w ówczesnych warunkach wyprodukować kilka niezwykle ważnych dzieł $\mathrm{w}$ historii chorwackiej kinematografii, między innymi Slučajni život [Przypadkowe życie; jedyna pełnometrażowa fabuła prekursora chorwackiej myśli filmoznawczej, Ante Peterlicia][5] oraz arcydzieło Tomislava Radicia - Živa istina [Żywa prawda] z 1972 roku[6]. Film Radicia wywołał prawdziwą burzę: $\mathrm{z}$ powodu pseudodokumentalnego stylu (a najpewniej i przez subtelną prowokację polityczną) nie został włączony do oficjalnego programu Festiwalu Filmowego w Puli[7], jednak odtwórczyni głównej roli, Božidarce Frajt, wbrew regulaminowi przyznano główną nagrodę za pierwszoplanową rolę kobiecą [8].

Jak pisze Ivo Škrabalo, proces decentralizacji i częściowej liberalizacji chorwackiej kinemato- grafii zakończył się dopiero w drugiej połowie lat sześćdziesiątych XX wieku, stąd największa liczba kluczowych realizacji kina autorskiego powstała w latach 1966-1969 (w 1966 roku Rondo [Rondo] Zvonimira Berkovicia, Ponedjeljak

[3] Polskie odpowiedniki tytułów pojawiających się w tekście filmów chorwackich, które miały dystrybucję w Polsce, podaję zgodnie z ich oficjalną wersją - należą do nich: $H-8$... (H-8..., 1958), Prometeusz z Dalmacji (Prometej s otoka Viševice, 1964), Trzy klucze (Ključ, 1965); Poniedziałek albo wtorek (Ponedjeljak ili utorak, 1966); Rondo (Rondo, 1966); Brzoza (Breza, 1967); 2 mamy, 2 ojców (Imam 2 mame i 2 tate, 1968); Grawitacja (Gravitacija ili fantastična mladost činovnika Borisa Horvata, 1968); Zdarzenie (Događaj, 1969), Kajdanki (Lisice, 1969); Stuchajcie bicia dzwonów (Kad čuješ zvona, 1969); Mirra, kadzidło i złoto (Mirisi, zlato i tamjan, 1971); Okupacja w 26 obrazach (Okupacija u 26 slika, 1978). Tytuły pozostałych filmów podaję we własnym przekładzie - przyp. tłum.

[4] Ogniwem napędzającym FAS był wszechstronnie uzdolniony producent (zajmował się też m.in. fotografią i reżyserią) - Kruno Heidler. [5] O Ante Peterliciu jako filmoznawcy i reżyserze przeczytać można w pracy zbiorowej: 3-2-1, KRENI! Zbornik radova u povodu 70 . rođendana Ante Peterlića, red. N. Gilić, Zagreb 2006 (tu szczególnie: tekst reżysera i krytyka filmowego Zorana Tadicia) oraz w artykule Hrvoje Turkovicia: Paradigma Peterlić, „Hrvatski filmski ljetopis” 2007, nr 51 (XII), s. 3-11.

[6] Por. I. Škrabalo, Hrvatska filmska..., 2008, s. 99.

[7] Dzisiejszy Festiwal Filmowy w Puli (Pulski filmski festival) nosił wówczas nazwę Festiwal Jugosłowiańskiego Filmu Fabularnego (Festival jugoslavenskog igranog filma) - przyp. tłum. [8] Warto wspomnieć, że wśród krytyków filmowych, walczących o włączenie do festiwalowego programu radykalnie modernistycznego filmu Živa istina, przodował „hitchcockowiec” („hičkokovac”; patrz przypis nr 17), Petar Krelja erudyta i aktywny uczestnik wydarzeń filmowych w Chorwacji i Jugosławii. Por. P. Krelja, Vladekov stol, „Hrvatski filmski ljetopis” 1995, nr 1/2 (I), s. 34-39; idem, Režiseri i kritičari, „Hrvatski filmski ljetopis” 2001, nr 27/28 (VII), s. 32-49; idem, Mali oglasi ili (ne)uhvatliivost dokumentaraca, „Hrvatski filmski ljetopis” 2003, nr 33 (IX), s. 49-76. 
ili utorak [Poniedziatek albo wtorek] Vatroslava Mimicy; w 1967 roku Breza [Brzoza] Ante Babai, Kaja, ubit ću te! [Kaja, zabiję cię!] Vatroslava Mimicy, Iluzija [Iluzja] Krsta Papicia; w 1968 roku Gravitacija ili fantastična mladost činovnika Borisa Horvata [Grawitacja] Branka Ivandy, Imam 2 mame i 2 tate [2 mamy, 2 ojców] Kreša Golika; w 1969 roku Slučajni život Ante Peterlicia, Lisice [Kajdanki] Krsta Papicia, Događaj [Zdarzenie] Vatroslava Mimicy, Nedjelja [Niedziela] Lordana Zafranovicia, Kad čuješ zvona [Stuchajcie bicia dzwonów] Antuna Vrdoljaka)[9]. Należy jednak pamiętać, że "autorskie" pełnometrażowe filmy fabularne powstawały zarówno nieco wcześniej[10], jak i później - w latach siedemdziesiątych XX wieku (między innymi słynna, wspomniana już, Živa istina Radicia).

Podsumowując, niezadowoleniu (zarówno krytyków filmowych, jak i partyjnych dygnitarzy) z efektów działalności tak zwanej produ-

[9] Por. I. Škrabalo, 101 godina filma..., 1998; idem, Hrvatska filmska..., 2008.

[10] Wymieniając choćby: Svanuće [Świt, 1964] Nikoli Tanhofera, Prometej s otoka Viševice [Prometeusz z Dalmacji, 1964] Vatroslava Mimicy, Ključ [Trzy klucze, 1965] Vančy Kljakovicia, Krsta Papicia i Antuna Vrdoljaka.

[11] Film Carevo novo ruho - pod względem poetyki i stylu będący wyraźnie autorską realizacją - w całości powstał w ramach producenckiej kinematografii. Niezasłużony brak sukcesu z pewnością opóźnił kontynuowanie przez Babaję pracy nad pełnometrażowymi filmami fabularnymi.

[12] Więcej na ten temat w: N. Gilić, „Kameni horizonti" - model socrealističke prezentacije i hrvatska kultura pedesetih, [w:] Komparativna povijest hrvatske književnosti $V$, red. M. Tomasović, V. Glunčić-Bužančić, Split 2003, s. 159-169; idem, Recepcija „Koncerta” Branka Belana. Moderna mitologia napretka kao kriterij vrednovanja, [w:] Komparativna povijest hrvatske književnosti VIII, red. C. Pavlović, V. Glunčić-Bužančić, Split 2006, s. 224-238. Więcej na temat jugosłowiańskiego socrealizmu w: V. Mataga, Književna kritika i ideologija, Zagreb 1995.

[13] Hrvoje Turković właśnie Antę Babaję uważa za autora kluczowego w procesie afirmacji filmu cenckiej kinematografii poprzedniego okresu (lat pięćdziesiątych i początku sześćdziesiątych) towarzyszył wzrost znaczenia autorów filmów (co w kontekście filmowym rozumiane jest przede wszystkim jako wzrost znaczenia reżyserów), którzy rozwijali różnorodne, jednak wyjątkowo zharmonizowane poetyki i tradycje.

\section{Tradycje i innowacje modernizmu}

Europejski modernizm jest pierwszą tradycją, która odziedziczyła po romantyzmie ideę autorstwa - na swój sposób ją modyfikując. Modernistą był pisarz (swoją drogą: Chorwat) Miroslav Krleža - „dworski artysta” (wpływowy arbiter nie tylko w kwestiach estetycznych) prezydenta federacji Josipa Broza-Tity, ale także część przedstawicieli modernistycznej poetyki w chorwackim i jugosłowiańskim kinie przyjęła komunistyczną ideologię oraz państwową politykę (na przykład Vatroslav Mimica i Lordan Zafranović). Niezależnie od stopnia prowokacyjności niektórych filmów przedstawicieli autorskiej kinematografii w Chorwacji i pozostałych republikach SFRJ (np. Carevo novo ruho [Nowe szaty cesarza] - pełnometrażowy debiut Ante Babai z 1961 roku, Lisice Papicia czy Mirisi, zlato i tamjan [Mirra, kadzidło i złoto] Babai Z 1971 roku)[11], sama idea autorstwa w żaden sposób nie wpisuje się w podziemny nurt chorwackiej i jugosłowiańskiej kultury.

Tradycja modernizmu stanowiła bowiem "legitymizującą" orientację epoki, przystającą do ówczesnych dążeń jugosłowiańskiej kultury zmierzającej do wypracowania własnej drogi artystycznej ulokowanej między zachodnim konsumpcjonizmem i wschodnim socrealizmem[12]. W ramach poetyki modernistycznej bez wątpienia powstał zarówno fabularny, jak i dokumentalny dorobek filmowy Ante Babai[13] oraz Zvonimira Berkovicia - dwóch wiodących przedstawicieli chorwackiego filmu autorskiego, którzy nie przyjęli ideologii jugosłowiańskiego państwa, a sposób na ekranizację swoich artystycznych idei znaleźli w ramach łagodnej liberalizacji, łącząc ruchome obrazy z tradycjami wysokiej kultury (literackimi, muzycznymi, malarskimi, teatralnymi). $\mathrm{W}$ trady- 
cje te kino chorwackie musiało się najpierw wpisać, by dopiero później móc się z nimi zrównać - jakkolwiek można dyskutować, czy proces legitymizacji sztuki filmowej został kiedykolwiek w pełni zrealizowany (w Chorwacji czy gdziekolwiek indziej).

Niewątpliwie, jak słusznie podkreśla Hrvoje Turković, na uprawomocnienie się modernistycznej twórczości filmowej lat sześćdziesiątych XX wieku miała wpływ słynna „zagrzebska szkoła filmu animowanego" oraz zrealizowane w modernistycznym duchu dekadę wcześniej krótkometrażowe filmy fabularne i dokumentalne[14]. Nie można też zignorować zjawisk obecnych w muzyce i sztukach wizualnych, jak choćby działalności grupy artystycznej EXAT51 na początku lat pięćdziesiątych XX wieku. Jednym z jej członków był Vladimir Kristl, malarz, wybitny autor modernistycznych animacji i krótkich fabuł, który na skutek ideologicznej nieprawomyślności obecnej w jednym z filmów (General i pravi čovjek [Generat i prawdziwy człowiek] z 1962 roku)[15], artystyczną i pedagogiczną działalność kontynuował za granicą, w Republice Federalnej Niemiec.

Ta starsza kulturowa tradycja modernizmu, pomyślnie uprawomocniona decyzjami politycznych mocodawców, była spójna $\mathrm{z}$ tradycją młodszą - typowo filmową, zrodzoną na początku lat sześćdziesiątych, gdy na europejską scenę $\mathrm{z}$ rozmachem weszli francuscy twórcy: Jean-Luc Godard, Claude Chabrol i François Truffaut, z czasem zajmując centralne miejsce w kanonie europejskiego modernizmu i filmu autorskiego drugiej połowy XX wieku. Buntownicy ci, z jednej strony, mieli wpływ na chorwackich reżyserów i krytyków filmowych (Ante Peterlić, Branko Ivanda, Krsto Papić, Petar Krelja, Zoran Tadić, Vladimir Vuković $\mathrm{i}$ in.), $\mathrm{z}$ drugiej zaś - dali autorskim realizacjom filmowym alternatywną, kontrkulturową legitymizację. W odróżnieniu bowiem od reżyserów proreżimowych - Mimicy i Zafranovicia[16], a także autorów klasyczno-modernistycznych Babai i Berkovicia, chorwaccy "hitchcockowcy” [„,hičkokovci”] (jak naśladowców francuskiego kina autorskiego ironicznie nazwał Fadil
Hadžić) [17] przejęli modernistyczną poetykę swoich zagranicznych mistrzów, jednocześnie podzielając ich upodobanie do wielkich twórców klasycznej kinematografii amerykańskiej (Ford, Hitchcock, Hawks itd.). Amerykanofilia wiodących nowofalowców (czego przykładem mogą być choćby liczne odwołania do tamtej kultury w klasyku Godarda Do utraty tchu) musiała imponować młodym, zorientowanym intelektualnie filmowcom chorwackim, mocno oddalonym zarówno od głównego nurtu socjalistycznej kultury, jak i chorwackiej tradycji

jako sztuki w kulturze chorwackiej. Por. H. Turković, Filmske pedesete, „Hrvatski filmski ljetopis” 2005, nr 41 (XI), s. 122-131; idem, Umjetnost kao osobni program, [w:] Ante Babaja, red. A. Peterlić, T. Pušek, Zagreb 2002, s. 37-56.

[14] H. Turković, Filmske pedesete..., s. 264-314.

[15] Film General i resni človek (można też spotkać wersję tytułu Resni človek), zrealizowany przez słoweńską wytwórnię filmową Viba Film, zawiera przejrzystą aluzję do postaci Josipa Broza-Tity, w wyniku czego, jak łatwo się domyślić, był zabroniony.

[16] Ta polityczna charakterystyka nie ma związku z artystyczną wartością filmów wspomnianych autorów - Vatroslav Mimica jest być może najlepszym chorwackim reżyserem filmów fabularnych lat sześćdziesiątych XX wieku.

[17] Uszczypliwym żartem (który w oryginalnej wypowiedzi brzmiał „ičkokovci” - brak pierwszej litery miał sygnalizować prowincjonalizm) Hadžić przewrotnie nawiązał do Alfreda Hitchcocka - reżysera, który spośród największych przedstawicieli kanonu zachodniej kinematografii realizował filmy „najniższego gatunku”. Hadžić jako twórca thrillerów, a później również horrorów, mógł sobie pozwolić na dyskredytację nowej „młodzieży” filmowej tak w oczach komunistów, jak i zwolenników modernistycznej kultury wysokiej. Z czasem, gdy kanon filmowy - za sprawą rozwoju krytyki i filmoznawstwa (Peterlić!), był obecny również w Chorwacji, Hadžić zaczął twierdzić, że określenie „hičkokovci” służyło jedynie opisowi, a nawet, że zostało wypowiedziane z sympatią. Znamienne jest, iż Hadžić jako reżyser bliski był „autorskim” tendencjom, podobnie jak skłaniał się w stronę filmu partyzanckiego i innych wiodących nurtów filmowych w kinematografii chorwackiej. 
152

VARIA

modernizmu spod znaku Krležy. Nie może dziwić, że ci młodzi zagrzebscy krytycy filmowi mieli ogromne trudności z rozpoczęciem kariery reżyserskiej. Zoran Tadić i Petar Krelja do kinematografii weszli „bocznymi drzwiami”, pracując dla telewizji (Zoran Tadić) lub realizując krótkie fabuły (Petar Krelja)[18], filmem Peterlicia Slučajni život socjalistyczna kinematografia chorwacka (w odróżnieniu od francuskiej krytyki) wzgardziła, a dorobek Branka Ivandy - mimo znakomitego debiutu - okazał się ostatecznie stosunkowo niewielki[19].

Wydarzenia w oficjalnej jugosłowiańskiej i chorwackiej kulturze niespodziewanie nałożyły się więc nie tylko na modernistyczne tradycje (żywe zresztą w całej Europie Środkowej i Południowosłowiańskiej), ale też korespondowały $\mathrm{z}$ nowymi trendami utrzymanymi w tej poetyce (dla których inspiracje docierały właśnie z Paryża, tradycyjnie uznawanego za centrum kultury europejskiej), odznaczającymi się wyraźną orientacją prozachodnią. W efekcie, zamiast powoływać się na dobrze ugruntowane dziedziny sztu-

[18] Ze względu na fakt, że reżyser miał trudności ze zdobyciem funduszy, pełnometrażowy debiut fabularny Godišnja doba [Pora roku, 1979] stanowi połączenie trzech krótkometrażowych filmów: Usvojenje [Adopcja], Ferije [Ferie], Probni rok [Okres próbny].

[19] W jednym z wywiadów reżyser twierdził, że utrudnienia na drodze do realizacji filmu pełnometrażowego wynikały nie tyle z politycznej nieprawomyślności, co z faktu, że nie należał do żadnego partyjnego czy „środowiskowego” kręgu, który wpływał na decyzje dotyczące kinematografii w Chorwacji. Por. Nije zlo snimati Aralicu, dapače!, „Slobodna Dalmacija” 2002 (14-15.08.), $<$ http://arhiv.slobodnadalmacija.hr/20020814/ televizijao2.asp> [dostęp: 10.04.2018].

[20] Interesującą analizę dotyczącą chorwackiego modernizmu lat sześćdziesiątych XX wieku opublikował młody reżyser Miroslav Sikavica: U traganju za vlastitim izrazom, „Hrvatski filmski ljetopis” 2004, nr 37 (X), s. 139-153.

[21] Tytuł często jest podawany w tej skróconej wersji. Tłumaczenie pełnego tytułu brzmiałoby: Grawitacja albo fantastyczna młodość urzędnika Borisa Horvata. Jak wspomniano wcześniej, ki, więcej uwagi zaczęto poświęcać dziedzictwu filmowemu, patrząc na kulturę wysoką głównie przez pryzmat jej roli w życiu współczesnym[20].

W tym miejscu należy jednak postawić pytanie: czy autorstwo można utożsamić z modernizmem? W pierwszej chwili odpowiedź wydaje się zaskakująca: nie w pełni. $Z$ powyższego tekstu wynika co prawda, że te dwa pojęcia są ze sobą ściśle związane, nie należy jednak zapomnieć, iż o ile autorstwo dotyczyłoby przede wszystkim kwestii produkcji filmowej, o tyle modernizm odnosi się głównie do płaszczyzny artystycznej: poetyki i stylu. Ponadto, choć autorska koncepcja filmu na ogół wiąże się z modernizmem, to zawiera w sobie również tendencje realistyczne, zauważalne choćby we wpływie włoskiej (neo)realistycznej poetyki na wczesne filmy François Truffauta i Claude’a Chabrola, czy też $\mathrm{w}$ rysie naturalistycznym widocznym w dziełach takich reżyserów, jak Krsto Papić ( $L i-$ sice), Ante Babaja (Breza; Mirisi, zlato i tamjan). Wyraźnie naturalistyczny charakter miał film autorski w Serbii (realizacje takich twórców jak Živojin Pavlović i Aleksandar Petrović), dlatego w odniesieniu do tejże kinematografii częściej niż o modernizmie mówi się o „czarnej fali”. Niewątpliwie jednak Dušana Makavejeva czy Lazara Stojanovicia nazwać można modernistami, zdecydowanie bardziej radykalnymi w wielu swych poczynaniach twórczych niż większość chorwackich reżyserów filmów fabularnych.

\section{Przykład modernizmu: Gravitacija ili fan- tastična mladost činovnika Borisa Horvata Branka Ivandy}

Za wzorcowy przykład modernizmu w chorwackiej kinematografii lat sześćdziesiątych XX wieku może posłużyć wspomniany pełnometrażowy debiut fabularny Branka Ivandy Gravitacija[21] - dzieło, które korzysta z całego spektrum zabiegów filmowych typowych dla poetyki modernizmu.

W filmie wykorzystano motyw fotografii symbolizującej próbę zachowania („idealnej”) przeszłości: obecne są zarówno prawdziwe zdjęcia, które przekształcają się w żywe obrazy, jak też momenty, w których to filmowy obraz 
zostaje na dłużej zatrzymany. Swoistym przeciwieństwem fotografii staje się korzystanie z ruchu przyspieszonego, co stanowi czytelne nawiązanie metafilmowe do tradycji komedii slapstickowej. Dochodzą do tego długie ujęcia, nowoczesna muzyka, a nawet element animacji rysunkowej (przedstawienie eksplozji w końcowej części filmu). „Bohatera”, Borisa Horvata (Rade Šerberdžija), widz poznaje niebezpośrednio, bo przez monotonny głos towarzyszący kadrom przedstawiającym opustoszałe trybuny sportowe. Gdy zaś protagonista, zagubiony $\mathrm{w}$ przestrzeni miejskiej, pojawia się w kadrach znajduje się poza ich centralnym punktem. W ten sposób już początek filmowego obrazu sygnalizuje, że widz nie spotka tu bohatera klasycznego filmu narracyjnego - bohatera, który kieruje akcją i wpływa na otoczenie.

Horvat przejmuje nawyki i rutynę życia swojego ojca, emerytowanego urzędnika. Uświadamia sobie, że małżeństwo rodziców to zwykła iluzja, sam zaś - zamiast związać się z dziewczyną, którą jest zafascynowany - żeni się z tą, z którą wspólna egzystencja najprawdopodobniej okaże się powtórką losu rodziców. Ewentualne wątpliwości co do bezsensu „fantastycznej" egzystencji urzędniczej rozwiewa zakładowa wycieczka nad morze (śródziemnomorska przestrzeń odgrywa ważną rolę również w niektórych filmach Ante Babai i Vatroslava Mimicy): uczestnicy znęcają się nad mewą (malują ptaka czerwoną farbą i niezdolnego do lotu wyrzucają do morza)[22], szybko też ujawnia się szał Erosa (ponownie parodystyczne wykorzystanie przyspieszonego ruchu), któremu nieodłącznie towarzyszy siła Tanatosa (w czasie wycieczki umiera jeden ze starszych pracowników zakładu).

Branko Ivanda, mówiąc o rzeczywistości miejskiej bogatym, heterogenicznym językiem filmowym, typowym dla europejskiego modernizmu lat sześćdziesiątych XX wieku, dał wyraz tylko jednej z wielu autorskich koncepcji obecnych w kinematografii chorwackiej tej dekady. Tym bardziej można żałować, że nie stworzył on (jak choćby Vatroslav Mimica) obszernego i spójnego cyklu modernistycznych dzieł fil- mowych. Gravitacija realizuje wiele z naszkicowanych w powyższym tekście wyznaczników modernizmu - stąd właśnie ten tytuł (swoją drogą, kluczowy w karierze jednego z mistrzów chorwackiego i jugosłowiańskiego aktorstwa, Rade Šerberdžiji) może posłużyć nie tylko jako podsumowanie, ale również jako punkt wyjścia dla szerszej refleksji o modernizmie w chorwackiej kinematografii.

\section{Z języka chorwackiego przełożyła Urszula Putyńska}

B I B L I O G R A F I A

3-2-1, KRENI! Zbornik radova u povodu 70. rođendana Ante Peterlića, red. N. Gilić, Zagreb 2006

A Companion to Eastern European Cinemas, red. A. Imre, New York 2012

Ante Babaja, red. A. Peterlić, T. Pušek, Zagreb 2002

Filmska enciklopedija I-II, red. A. Peterlić, Zagreb 1986-1990

Filmski leksikon, red. B. Kragić, N. Gilić, Zagreb 2003

Gilić N., Filmske vrste i rodovi, Zagreb 2007

Gilić N., „Kameni horizonti” - model socrealističke prezentacije i hrvatska kultura pedesetih, [w:] Komparativna povijest hrvatske književnosti $V$, red. M. Tomasović, V. Glunčić Bužančić, Split 2003

Gilić N., Recepcija „Koncerta” Branka Belana. Moderna mitologija napretka kao kriterij vrednovanja, [w:] Komparativna povijest hrvatske književnosti VIII, red. C. Pavlović, V. Glunčić-Bužančić, Split 2006

Gilić N., Revolution, cinema, painting: creative recycling of images in the films of Tom Gotovac (Antonio Lauer), "Studies in Eastern European Cinema" 2010, nr 1

Goulding D.J., Liberated Cinema: The Yugoslav Experience 1945-2001, Indiana 2002

Krelja P., Mali oglasi, ili (ne)uhvatljivost dokumentaraca, „Hrvatski filmski ljetopis” 2003, nr 33 (IX)

Krelja P., Režiseri i kritičari, „Hrvatski filmski ljetopis” 2001, nr 27/28 (VII)

Krelja P., Golik, Zagreb 1997

również w Polsce film rozpowszechniony był pod krótszym wariantem tytułu: Grawitacja - przyp. tłum.

[22] W filmie obecne są również subtelniejsze prowokacje polityczne, które najpewniej uszły uwadze cenzorów. 
Krelja P., Vladekov stol, „Hrvatski filmski ljetopis” 1995, $\mathrm{nr} 1 / 2$ (I)

Mataga V., Književna kritika i ideologija, Zagreb 1995

Nije zlo snimati Aralicu, dapače!, „Slobodna Dalmacija” 2002 (14-15.08.)

$<$ http://arhiv.slobodnadalmacija.hr/20020814/televizija02.asp>

Peterlić A., Osnove teorije filma, Zagreb 2001

Sikavica M., U traganju za vlastitim izrazom, „Hrvatski filmski ljetopis" 2004, nr 37 (X)

Škrabalo I., Hrvatska filmska povijest ukratko (18962006), Zagreb 2008

Škrabalo I., 101 godina filma u Hrvatskoj 1896-1997. Pregled povijesti hrvatske kinematografije, Zagreb 1998
Škrabalo I., One hundred and one years of the Croatian film (1896-1997), <https://www.hrstud.unizg. hr/_download/repository/Ivo_Skrabalo_-_101_years_of_the_cinema_in_Croatia_-_Summary.pdf>

Turković H., Filmske pedesete, "Hrvatski filmski ljetopis" 2005, nr 41(XI)

Turković H., Paradigma Peterlić, „Hrvatski filmski ljetopis" 2007, nr 51(XII)

Turković H., Umjetnost kao osobni program, [w:] Ante Babaja, red. A. Peterlić, T. Pušek, Zagreb 2002, s. $37-56$ 